\title{
GABA and Neuropsychiatric Disorders
}

\author{
S.J. ENNA
}

SUMMARY: During the past decade a number of reports have appeared suggesting that alterations in GABAergic transmission may play a role in the symptoms of a variety of neurosychiatric disorders (Enna, 1980; Enna and Maggi, 1979). In the present communication, some of the evidence supporting this contention will be briefly summarized and reviewed.

RÉSUMÉ: Depuis une dizaine d'années plusieurs articles ont suggéré que des modifications de la transmission GABA ergique puissent jouer un rôle dans la génèse des symptômes d'une variété de désordres neuropsychiatriques (Enna. 1980; Enna et Maggi, 1979). Nous nous proposons d'analyser l'évidence à cet effet.

From the Departments of Pharmacology, Neurobiology, and Anatomy. University of Texas Medical School at Houston.

Reprint requests to S.J. Enna, Department of Pharmacology, University of Texas Medical School, P.O. Box 20708, Houston, Texas, U.S.A. 77025.

\section{NEUROLOGICAL DISORDERS}

Because GABA appears to be an important, if not the primary, inhibitory neurotransmitter in brain, it is not surprising to find biochemical, physiological and behavioral data indicating that activation of the GABAergic system may be efficacious in the treatment of epilepsy (Meldrum, 1975). In addition, a significant loss of GABA neurons has been noted around the seizure foci in monkey cortex after application of alumina gel (Ribek et al, 1979) and the GABA content of brain biopsy specimens from humans with focal epilepsy is reportedly reduced (Van Gelder et al, 1972). Furthermore, a significant reduction in cerebrospinal fluid GABA content has been found associated with myoclonic epilepsy (Enna et al, 1979).

Probably the strongest evidence linking GABA to neuropsychiatric diseases has been obtained from studies on extrapyramidal disorders. Thus, with regard to Huntington's disease, numerous laboratories have reported finding a decrease in GABA containing neurons in the basal ganglia and substantia nigra of the Huntington brain (Perry et al, 1973: Enna et al, 1976b). In addition GABA receptor binding is also altered in postmortem brain samples obtained from Huntington patients, being increased in some regions (substantia nigra and cerebellum) (Enna et al, 1976a; Lloyd and Davidson, 1979) and possibly decreased in the corpus striatum (Enna et al, 1976 a \& b; Lloyd et al, 1977b). Furthermore, cerebrospinal fluid analysis has revealed a decrease in the GABA content of this fluid (Enna et al, 1977). In addition, a recent report suggests that administration of GABAmimetics may be of benefit in treating the symptoms of this disease (Bartholini et al, 1979).
GABA has also been implicated in Parkinson's disease since extrapyramidal glutamic acid decarboxylase (GAD) activity, and GABA content, are significantly reduced in untreated patients (Hornykiewicz et al, 1976; Laaksonen et al, 1978). In addition, while GABA receptor binding is unaltered in most regions of the Parkinson brain, there is a significant decrease in this receptor in the substantia nigra, probably as a result of the loss of dopamine cells in this brain region (Lloyd et al, 1977a; Reisine et al, 1977). To date, however, attempts to treat this disorder by increasing brain GABA activity have proven unsuccessful (Barbeau, 1973).

Another neurological disorder that has been investigated is Alzheimer's disease, the most common form of presenile dementia. The results of this study indicate that there are regionally selective decreases in the number of GABA receptors in postmortem brain samples (Reisine et al, 1978). Specifically, both the cerebral cortex and corpus striatum had fewer GABA receptors than age-matched controls, whereas the hippocampal GABA receptors appear intact. This apparent loss of GABA receptors is undoubtedly related to the characteristic neuronal degeneration found in this disorder. However, it is impossible to predict which, if any, of the symptoms of Alzheimer's disease are primarily related to this apparent loss of GABA receptor sites.

\section{SCHIZO-AFFECTIVE DISORDERS}

Evidence relating GABAergic dysfunction with the symptoms of schizophrenia and affective illness is, at this time, mostly indirect and highly speculative (Roberts, 1972: Maggi and Enna, 1980). With regard to schizophrenia, it has been hypothesized that 
since GABA exerts an inhibitory influence on mesolimbic dopamine neurons, the apparent dopaminergic overactivity in this brain area may be due to an underactive GABA influence. Even if this is not the case, it has been reasoned, GABAmimetics, by inhibiting this dopamine pathway, may be effective in this disorder.

Attempts to experimentally link a GABA abnormality to schizophrenia have so far met with little success. Thus, GAD activity is unchanged in schizophrenic brain (Iversen et al, 1979), and no alterations have been reported in the cerebrospinal fluid content of GABA and cerebral cortical GABA receptor binding (Lichtshtein et al, 1978; Bennett et al, 1979). In addition, treatment of schizophrenia with "GABAmimetic" agents has yet to yield positive results (Tamminga et al, 1978).

As opposed to schizophrenia, there is a scientific evidence, albeit indirect, linking GABA with affective illnesses. Thus, lithium, an ion known to be effective in treating manic-depressive psychosis, affects both GABA uptake and release in vitro (Snodgrass et al, 1973; Katz et al, 1969) and, when given chronically, causes regionally selective changes in brain GABA content and GABA receptor binding (Gottesfeld, 1976; Maggi and Enna, 1980). While much further work is necessary to prove that these effects are primary and, beyond that, that a GABA abnormality is causative in this disorder, it is conceivable that some of the actions of lithium are related to an alteration in GABA function.

\section{GABA THERAPY}

The approaches which have been taken to develop GABAmimetic agents include the synthesis of drugs which inhibit the metabolism of this amino acid, thereby increasing brain content and, presumably, the functional activity of GABA. Also, a number of direct acting GABA receptor agonists have been reported. While published clinical studies are sparse, preliminary data has indicated that these drugs may be useful in a wide variety of central nervous system disorders (Bartholini et al, 1979). In addition, the recent availability of systematically active
GABAmimetics has spawned a number of preclinical studies, the results of which may better define the therapeutic, and side effect, potential of these agents (Ferkany et al, 1980; Ferkany and Enna, 1980). For example, recent reports have indicated that chronic administration of GABAmimetics leads to GABA and dopamine receptor alterations in the basal ganglia as well as changes in cholinergic activity in this brain region. From these and other results it may be predicted that long-term GABAmimetic therapy may be of benefit in disorders characterized by an overabundance of nigrostriatal dopamine activity (Huntington's disease) but may be of no value, and perhaps may exacerbate, the symptoms of disorders characterized by underactivity in this dopamine pathway (Parkinson's disease).

In summary, while the data linking GABA to any given illness is still preliminary, the weight of evidence in general would seem to favor the notion that pharmacological manipulation of the GABA system should have some therapeutic value. Because of the current interest in GABA pharmacology, it seems likely that a more precise relationship between GABA and neuropsychiatric disorders will be established in the near future.

\section{ACKNOWLEDGEMENTS}

Preparation of this manuscript was facilitated by USPHS grants NS-13803 and NS-00335.

\section{REFERENCES}

BARBEAU, A. (1973). GABA and Huntington's Chorea. Lancet ii, 1499-1500.

BARTHOLINI, G., SCATTON, B., ZIVIKOVIC, B. and LLOYD, K.G. (1979). On the mode of action of SL-76002, a new GABA receptor agonist. IN, GABA-Neurotransmitters, P. Krogsgaard-Larsen, J. ScheelKruger and H. Kofod (eds.), Munksgaard, Copenhagen, pp. 326-339.

BENNETT, J.P., ENNA, S.J., BYLUND, D.B., GILLIN, J.C., WYATT, R.J. and SNYDER, S.H. (1979). Neurotransmitter receptors in schizophrenic frontal cortex. Arch. Gen. Psychiat., 36, 927-934.

ENNA, S.J. (1980). Neuropharmacological and clinical aspects of $\gamma$-aminobutyric acid (GABA). IN, Neuropharmacology of Central and Behavioral Disorders, G. Palmer (ed.), Academic Press, New York, in press.
ENNA, S.J., BENNETT, J.P., BYLUND, D.B., SNYDER, S.H., BIRD, E.D. and IVERSEN, L.L. (1976a). Alterations of brain neurotransmitter receptor binding in Huntington's disease. Brain Res., 116, 531-537.

ENNA, S.J., BIRD, E., BENNETT, J.P., BYLUND, D.B., YAMAMURA, H.I., IVERSEN, L.L. and SNYDER, S.H. (1976b). Huntington's chorea: changes in neurotransmitter receptors in brain. New Eng. J. Med., 294, 1305-1309.

ENNA, S.J., FERKANY, J.W., VAN WOERT, $M$. and BUTLER I.J. (1979). Measurement of GABA in biological fluids: effects of GABA transaminase inhibitors. IN, Advances in Neurology, Vol. 23, T. Chase, N. Wexler and A. Barbeau (eds.), Raven Press, New York, pp. 741-750.

ENNA, S.J. and MAGGI, A. (1979). Biochemical pharmacology of GABAergic agonists. Life Sci., 24, 1727-1738.

ENNA, S.J., STERN, L.Z., WASTEK, G.J. and YAMAMURA, H.I. (1977). Cerebrospinal fluid $\gamma$-aminobutyric acid variations in neurological disorders. Arch. Neurol., 34, 683-685.

FERKANY, J.W. and ENNA, S.J. (1980). Interaction between GABAergic agonists and the cholinergic muscarinic system in rat brain. Life Sci., in press.

FERKANY, J.W., STRONG, R. and ENNA, S.J. (1980). Striatal dopamine receptor super-sensitivity in response to chronically elevated brain GABA content. J. Neurochem., 34, 247-249.

GOTTESFELD, Z. (1976). Effect of lithium and other alkali metals on brain chemistry and behavior. Psychopharmacologia, 45, 239242.

HORNYKIEWICZ, O., LLOYD, K.G. and DAVIDSON, L. (1976). The GABA system and function of the basal ganglia-Parkinson disease. IN, GABA in Nervous System Function, E. Roberts, T. Chase and D. Tower (eds.), Raven Press, New York, pp. 479-485.

IVERSEN, L.L. BIRD, E., SPOKES, E., NICHOLSON, S.H. and SUCKLING, C.J. (1979). Agonist specificity of GABA binding sites in human brain and GABA in Huntington's disease and schizophrenia. IN, GABA-Neurotransmitters, P. KrogsgaardLarsen, J. Scheel-Kruger and H. Kofod (eds.), Munksgaard, Copenhagen, pp. 179190.

KATZ, R.I., CHASE, T.N. and KOPIN, I.J. (1969). Effects of ions on stimulus-induced release of amino acids from mammalian brain slices. J. Neurochem. 16, 961-967.

LAAKSONEN, H., RINNE, U.K., SONNINEN, V. and RIEKKINEN, P. (1978). Brain GABA neurons in Parkinson's disease. Acta Neurol. Scand. Suppl. 67, 57, 282-283.

LICHTSHTEIN, D., DOBKIN, J., EBSTEIN, R.P., BIEDERMAN, J., RIMON, R. and BELMAKER, R.H. (1978). Gamma-aminobutyric acid (GABA) in the CSF of schizophrenic patients before and after neuroleptic treatment. Brit. J. Psychiat., 132, 145148. 
LLOYD, K.G. and DAVIDSON, L. (1979). ${ }^{3} \mathrm{H}-$ GABA binding in brains from Huntington's chorea patients: altered regulation by phospholipids? Science, 205, 1147-1149.

LLOYD, K.G., DRESKLER, S. and BIRD, E.D. (1977b). Alterations in ${ }^{3} \mathrm{H}-\mathrm{GABA}$ binding in Huntington's chorea. Life Sci., 21, 747-753.

LLOYD, K.G., SHEMEN, L. and HORNYKIEWICZ, O. (1977a). Distribution of high affinity sodium independent ${ }^{3} \mathrm{H}$-gammaaminobutyric acid ( $\left.{ }^{3} \mathrm{H}-\mathrm{GABA}\right)$ binding in the human brain: alterations in Parkinson's disease. Brain Res., 127, 269-278.

MAGGI, A. and ENNA, S.J. (1980). Regional alterations in rat brain neurotransmitter systems following chronic lithium treatment. J. Neurochem., 34, 888-892.

MELDRUM, B.S. (1975). Gamma-aminobutyric acid and the search for new anticonvulsant drugs. Lancet, ii, 304-306.

PERRY, T.L., HANSEN S. and KLOSTER, $M$. (1973). Huntington's chorea, deficiency of gamma-aminobutyric acid in brain. New Eng. J. Med., 288, 337-342.

REISINE, T.D., FIELDS, J.Z., YAMAMURA H.I., BIRD, E., SPOKES, E., SCHREINER, P. and ENNA, S.J. (1977). Neurotransmitter receptor alterations in Parkinson's disease. Life Sci., 21, 335-344.

REISINE, T.D., YAMAMURA, H.I., BIRD E.D., SPOKES, E. and ENNA, S.J. (1978). Pre- and postsynaptic neurochemical alterations in Alzheimer's disease. Brain Res., 154, 477-481.

RIBAK, C.E., HARRIS, A.B., VAUGHN, J.E. and ROBERTS, E. (1979). Inhibitory, GABAergic nerve terminals decrease at sites of focal epilepsy. Science, 205, 211-214.

ROBERTS, E. (1972). An hypothesis suggesting that there is a defect in the GABA system in schizephrenia. Neurosci. Res., Progr. Bull., $10,468-480$.

SNODGRASS, S.R., HEDLEY.WHYTE, E.T. and LORENZO, A.V. (1973). GABA transport by nerve ending fractions of cat brain. J. Neurochem., 20, 771-782.

TAMMINGA, C.A., CRAYTON, J.W. and CHASE, T.C. (1978). Muscimol: GABA agonist therapy in schizophrenia. Amer. J. Psychiat. 135, 746-747.

VAN GELDER, N.M., SHERWIN, A.L. and RASMUSSEN, T. (1962). Amino acid content of epileptogenic human brain; focal versus surrounding regions. Brain Res., 40. 385-393. 